\title{
Effect of clearance of bacteria from the blood on the development of systemic bacteraemia in mice
}

\author{
Y. HIRAKATA, M. KAKU*, N. FURUYA, T. MATSUMOTO*, K. TATEDA, K. TOMONO $\dagger$ and \\ K. YAMAGUCHI
}

Department of Microbiology, Toho University School of Medicine, Tokyo 143, and * Department of Laboratory Medicine, and † Department of 2nd Internal Medicine, Nagasaki University School of Medicine, Nagasaki 852, Japan

\begin{abstract}
Summary. Clearance of various bacteria isolated from portal and systemic blood of mice was evaluated and compared. All portal blood strains, including Escherichia coli and enterococci were eliminated more rapidly from the circulation than were strains isolated from systemic blood, including Pseudomonas aeruginosa. With mannose-type lectin, mannose or fucose residues that mediated lectinophagocytosis were detected on the surfaces of most portal strains by agglutination tests. Blood clearance of Esch. coli $\mathrm{H} 21$ was inhibited by prior injection of mannose into mice, suggesting that the clearance of this strain was mediated by mannose-type lectin on the surface of tissue macrophages. However, no inhibition of clearance of any other strains was observed by the injection of mannose, galactose, or fucose into mice, nor by pre-incubation of bacteria with mannose. Blood clearance of some portal strains was significantly faster in CBA/J mice than in CBA/N mice with $B$ cell immune deficiency, indicating that immunoglobulin was involved in their clearance. Among portal strains only enterococci showed high cell-surface hydrophobicity. These data suggest that initial bacterial blood clearance may be critical in determining whether latent portal bacteraemia progresses to systemic bacteraemia and that the rapid clearance of most strains is multifactorial.
\end{abstract}

\section{Introduction}

The reticuloendothelial system (RES) plays a key role in removing micro-organisms, endotoxins and other particles from the circulation, ${ }^{1-4}$ and hepatic phagocytosis by Kupffer cells accounts for $>80 \%$ of RES function. ${ }^{5,6}$ Non-opsonic phagocytosis by Kupffer cells, such as lectinophagocytosis ${ }^{7}$ and hydrophobic interaction ${ }^{8}$, may be an important mechanism in clearance of bacteria from the bloodstream and in host defence against bacteraemia. ${ }^{9}$ Lectinophagocytosis can be mediated by both bacterial and macrophage surface lectins. ${ }^{7}$ Lectinophagocytosis of Escherichia coli mediated by the mannose-specific lectin associated with type 1 fimbriae has been investigated extensively. ${ }^{10,11}$ Mannose-specific lectin on the bacterial surface of some Klebsiella pneumoniae strains also mediates lectinophagocytosis." At least three types of lectin, i.e., mannose-, galactose-, and fucose-type lectin, expressed on the surfaces of tissue macrophages have been isolated and characterised. ${ }^{7,12}$ Although there have been reports on the mechanism of elimination of bacteria from blood, ${ }^{13-15}$ studies comparing blood clearance of particular species of bacteria have been rare. ${ }^{4}$

We have reported that Pseudomonas aeruginosa and Morganella morganii frequently cause systemic bac- teraemia and that Esch. coli, enterococci, and other species caused portal bacteraemia only in cyclophosphamide-treated mice. ${ }^{16}$ The viability of $P$. aeruginosa D4 and $M$. morganii L48, that cause systemic bacteraemia, is not affected by the Kupffer cells and these bacteria are not eliminated from the blood. In contrast, Esch. coli L424, Enterobacter cloacae L522, K. pneumoniae H27, and Enterococcus faecalis L425, present in portal blood, are gathered up by the Kupffer cells, and eliminated rapidly from the circulation.

The present study evaluated and compared clearance from the bloodstream of various bacterial strains isolated from mice following their intravenous administration via the tail vein. Potential roles of cell-surface sugars and lectins and bacterial cell-surface hydrophobicity in mediating bacterial clearance from the blood of mice were also examined, as well as the influence of immunoglobulin on clearance.

\section{Materials and methods}

\section{Bacterial strains}

Bacterial strains were isolated from mice with bacteraemia produced by the administration of cyclophosphamide and ampicillin as described previously ${ }^{16}$ (table I). Strains were considered to be resistant to serum if $100 \%$ viability was maintained after incubation for $60 \mathrm{~min}$ in fresh normal murine serum. 
Table I. Bacterial strains

\begin{tabular}{|c|c|}
\hline Systemic & Portal \\
\hline$P$. aeruginosa D4 & Esch. coli $\mathrm{L} 33$ \\
\hline P. aeruginosa D271 & Esch. coli L424 \\
\hline$P$. aeruginosa $\mathrm{H} 3$ & Esch. coli L529 \\
\hline P. aeruginosa $\mathrm{H} 8$ & Esch. coli $\mathrm{H} 21$ \\
\hline P. aeruginosa $\mathrm{H} 9$ & Esch. coli $\mathrm{H} 25$ \\
\hline P. aeruginosa $\mathrm{H} 12$ & E. cloacae L31 \\
\hline P. aeruginosa $\mathrm{H} 13$ & E. cloacae $\mathrm{L} 317$ \\
\hline P. aeruginosa $\mathrm{H} 15$ & E. cloacae L522 \\
\hline M. morganii L48 & E. cloacae L527 \\
\hline M. morganii $\mathrm{L} 222$ & K. pneumoniae $\mathrm{H} 29$ \\
\hline M. morganii L 322 & Ent. faecalis $\mathrm{L} 425$ \\
\hline M. morganii L421 & Ent. faecium L211 \\
\hline M. morganii $\mathrm{H} 32$ & Ent. faecium L410 \\
\hline M. morganii $\mathrm{H} 35$ & \\
\hline
\end{tabular}

Such strains could be separated into two groups. $P$. aeruginosa and $M$. morganii strains isolated from both cardiac and portal blood were defined as systemic strains. The other strains were isolated from portal blood only and were defined as portal strains.

\section{Media}

Bacteria were grown on Trypticase Soy Agar (TSA; BBL Microbiology Systems, Cockeysville, MD, USA) at $37^{\circ} \mathrm{C}$ for $24 \mathrm{~h}$. Bacteria originating from a single colony were incubated in Mueller-Hinton broth (Difco Laboratories, Detroit, MI, USA), washed with sterile saline, and adjusted to a suitable concentration for each experiment in saline by optical density measured with a spectrophotometer.

\section{Clearance of bacteria from mouse blood}

Clearance was evaluated as described previously. ${ }^{16}$ Into specific-pathogen-free (SPF) male ddY mice weighing $20-24 \mathrm{~g}, 0.2 \mathrm{ml}$ of a bacterial suspension in saline containing $10^{8} \mathrm{cfu} / \mathrm{ml}$ was injected in the tail vein. After injection, blood samples were obtained sequentially from the retro-orbital plexus into disposable heparinised capillary tubes, diluted in saline, and plated on TSA. The zero time values were calculated by estimating total blood volume as $8 \%$ $\mathrm{v} / \mathrm{w}$ of each body weight of the mice used. ${ }^{13}$ Results are expressed as the mean recovery percentage in five mice.

\section{Screening for mannose sensitivity and bacterial surface sugars}

To examine the mannose sensitivity of bacterial strains, bacterial suspensions were mixed with mannosylated taxonobeads (E-Y Laboratories, Inc., San Mateo, CA, USA) in the absence or presence of $0 \cdot 25 \mathrm{M}$ a

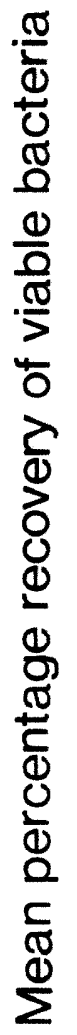

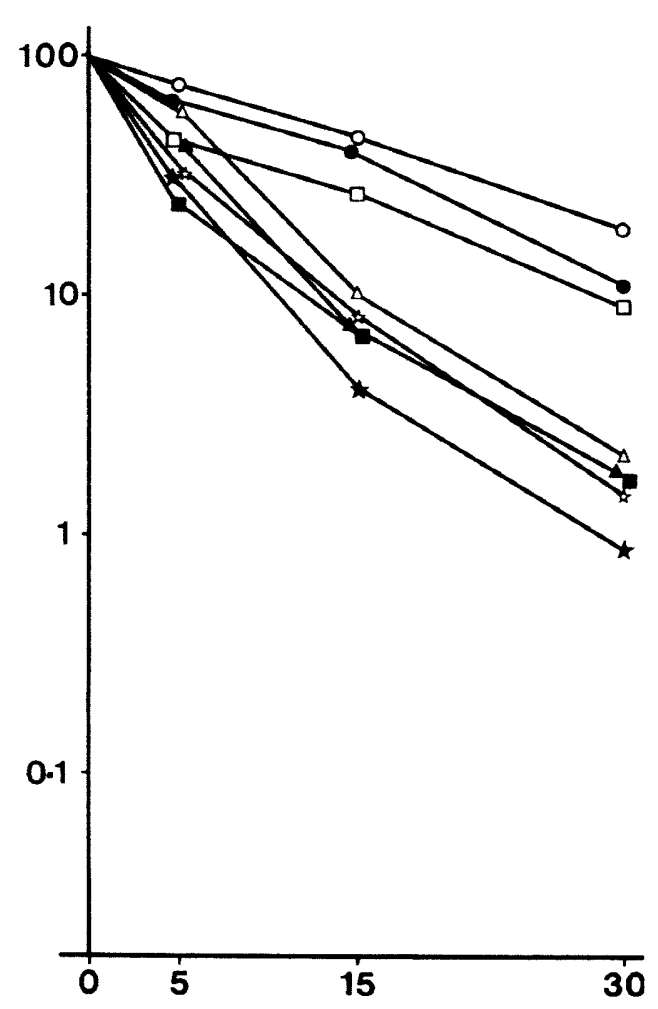

b

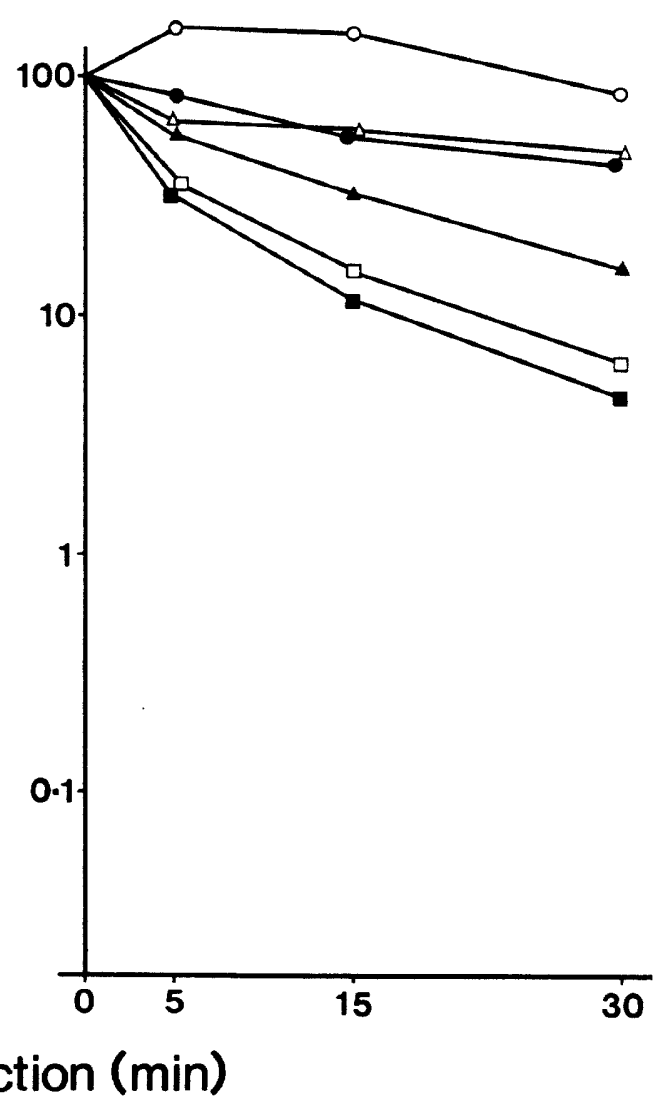

Fig. 1. Clearance of systemic strains from blood in mice. Results are expressed as the mean recovery percentages in five mice. (a) $P$. aeruginosa

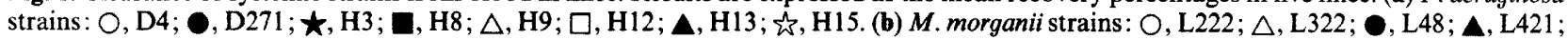
$\square, \mathrm{H} 32 ; \square, \mathrm{H} 35$. 


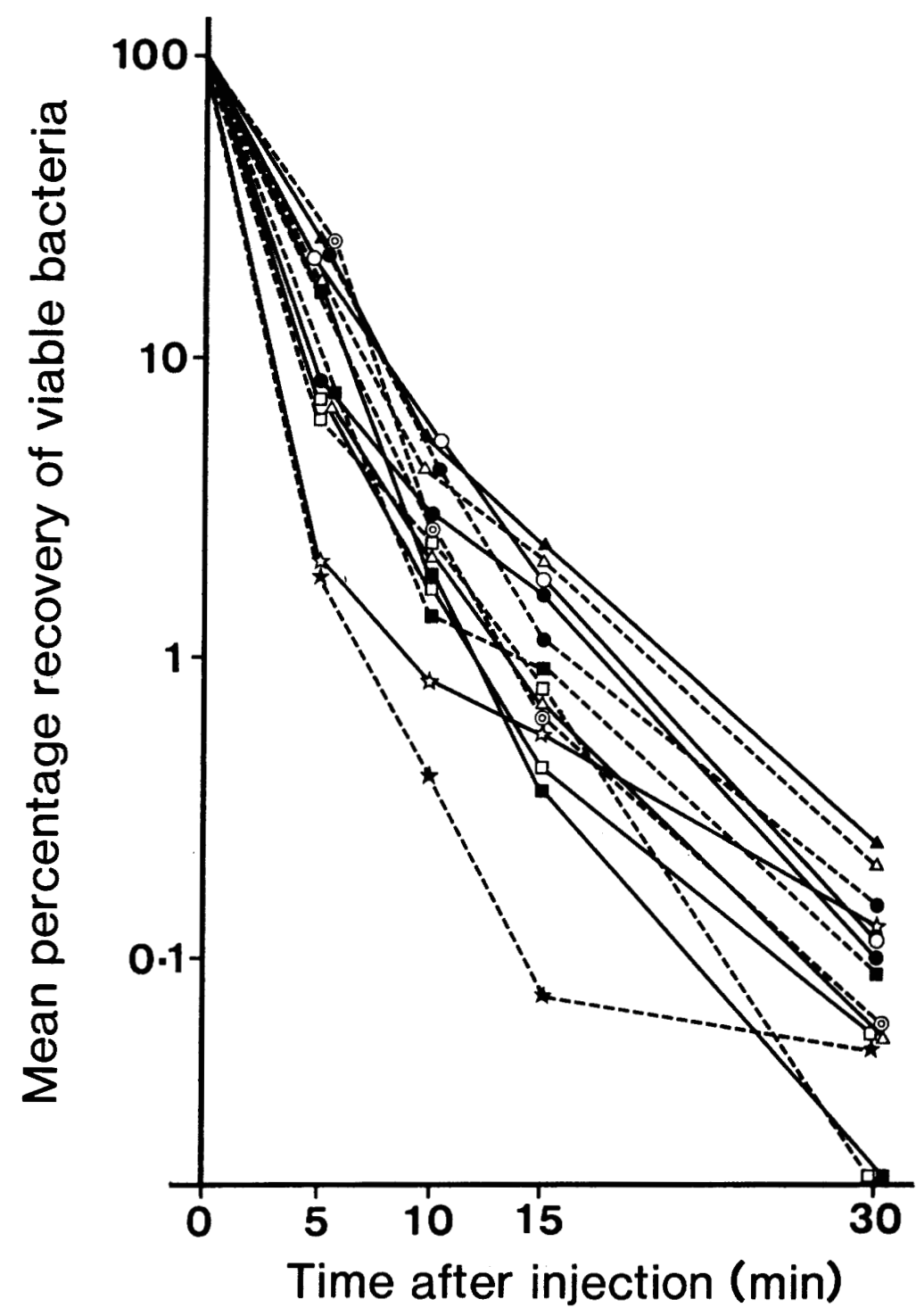

Fig. 2. Clearance of portal strains from blood in mice. Results are expressed as the mean recovery percentages in five mice. The clearance of portal strains was significantly faster than that of systemic strains, i.e., $P$. aeruginos $a$ and $M$. morganii at all time intervals $(\mathrm{p}<0.01,0.02,0.05$ at 5, 15, 30 min after bacterial challenge, respectively): - $\square$, Esch. coli $\mathrm{L} 33 ;-\star-$, Esch. coli $\mathrm{L} 424 ;--\square$, Esch. coli $\mathrm{L} 529 ;-\mathbf{\square}$, Esch coli $\mathrm{H} 21$;

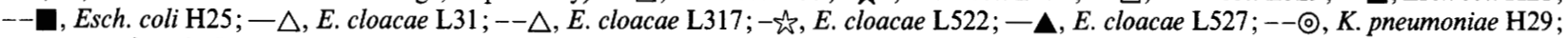
$-\mathrm{O}$, Ent. faecalis L425; -, Ent. faecium L211; -- Ent. faecium L410.

D-mannose (Nacalai Tesque Inc., Kyoto, Japan) on a slide as described previously. ${ }^{16}$ Agglutination inhibited by mannose was considered to be a positive result for mannose sensitivity. To examine the mannose and fucose on the surface of the bacteria, agglutination was examined with Concanavalin A (Vector Laboratories, Inc., Burlingame, CO, USA) and Ulex europaeus lectin I(UEA-I; Vector), each at a concentration of $1 \mathrm{mg} / \mathrm{ml}$.

\section{Inhibition of blood clearance by sugars}

Bacteria were incubated with or without $100 \mathrm{~mm}$ D-mannose at $37^{\circ} \mathrm{C}$ for $30 \mathrm{~min}$. After washing with saline, bacteria were injected into mice as described above. In some experiments, $100 \mathrm{mg}$ of D-mannose, D-galactose and D-fucose (Wako Pure Chemical Industries, Ltd, Osaka, Japan) was injected intravenously 10 min before bacterial challenge.

\section{Assessment of bacterial cell-surface hydrophobicity}

Cell-surface hydrophobicity was determined by adherence to liquid hydrocarbon as described previously. ${ }^{17} \mathrm{~A}$ bacterial suspension at an optical density of 1.2 at $400 \mathrm{~nm}$ (1-cm cell width) determined with a spectrophotometer was added to n-hexadecane (Nacalai) (1 in 6), and the mixtures were agitated uniformly for $2 \mathrm{~min}$. After $15 \mathrm{~min}$, when the hydrocarbon phase had separated completely, the optical density at $400 \mathrm{~nm}$ of the bottom aqueous phase was read. Results are expressed as the percentage decrease in the absorbance of the aqueous phase compared with that of the initial cell suspension.

\section{Clearance of portal strains in $C B A / J$ and $C B A / N$} mice

Six-week-old male CBA/N (SPF) mice carrying an 
Table II. Agglutination of bacterial strains with mannosylated beads. Con A and UEA-I

\begin{tabular}{|c|c|c|c|}
\hline \multirow[b]{2}{*}{ Bacterial strain } & \multicolumn{3}{|c|}{ Agglutination with } \\
\hline & $\begin{array}{l}\text { mannosylated } \\
\text { beads }\end{array}$ & Con $\mathbf{A}$ & UEA-I \\
\hline Esch. coli $\mathbf{L} 33$ & - & + & - \\
\hline Esch. coli $\mathrm{L} 424$ & + & - & - \\
\hline Esch. coli $\mathrm{L} 529$ & - & - & - \\
\hline Esch. coli $\mathrm{H} 21$ & \pm & + & - \\
\hline Esch. coli $\mathrm{H} 25$ & + & + & - \\
\hline E. cloacae L31 & \pm & + & - \\
\hline E. cloacae $\mathrm{L} 317$ & + & + & + \\
\hline E. cloacae L522 & \pm & - & - \\
\hline E. cloacae L527 & + & + & \pm \\
\hline K. pneumonia $\mathrm{H} 29$ & - & + & - \\
\hline Ent. faecalis L425 & - & + & - \\
\hline Ent. faecium L211 & + & + & - \\
\hline Ent. faecium $\mathrm{L} 410$ & \pm & + & - \\
\hline$P$. aeruginosa D4 & - & + & - \\
\hline M. morganii L48 & - & - & - \\
\hline
\end{tabular}

$\mathrm{X}$-linked immune defect associated with the absence of mature or late developing B lymphocytes, ${ }^{18,19}$ and their normal counterpart, $\mathrm{CBA} / \mathrm{J}$ (SPF) mice, were used to examine the influence of immunoglobulin on blood clearance. Recovery percentages of Esch. coli L424 and L529, E. cloacae L317, and Ent. faecalis L525 from blood at $30 \mathrm{~min}$ after injection were compared in $\mathrm{CBA} / \mathrm{J}$ and $\mathrm{CBA} / \mathrm{N}$ mice. In other experiments, heat-inactivated serum, heat-inactivated serum absorbed with heat-killed Esch. coli L424, and heat-inactivated serum absorbed with heat-killed $E s c h$. coli $\mathrm{L} 529$ obtained from CBA/J mice were transferred $(0.2 \mathrm{ml}$ of serum/mouse) into $\mathrm{CBA} / \mathrm{N}$ mice. After $30 \mathrm{~min}$, blood clearance of Esch. coli L424 was compared in these mice.

\section{Statistical analysis}

Student's $t$ test was used to compare means, and a $p$ value of 0.05 was taken to be significant.

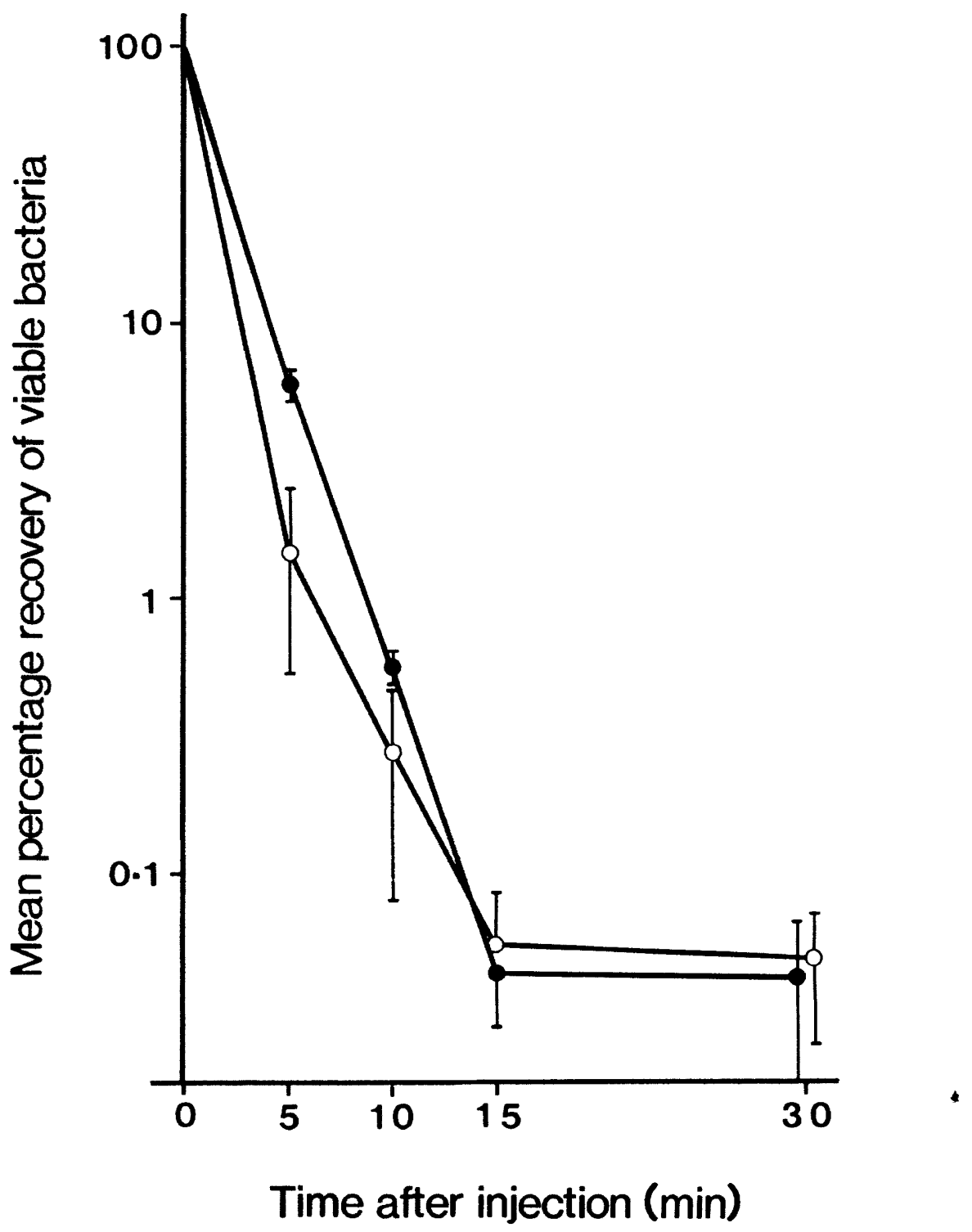

Fig. 3. Influence of pre-incubation of bacteria with D-mannose on clearance from blood in mice. Results are expressed as the mean recovery percentages (SD) in five mice. There was no significant difference between the clearance rates of mannose-treated Esch. coli L424 and those of the control;, Esch. coli $\mathrm{L} 424$ incubated with $100 \mathrm{~mm}$ D-mannose for $30 \mathrm{~min}$ at $37^{\circ} \mathrm{C}$ before injection; $\bigcirc$, control. 


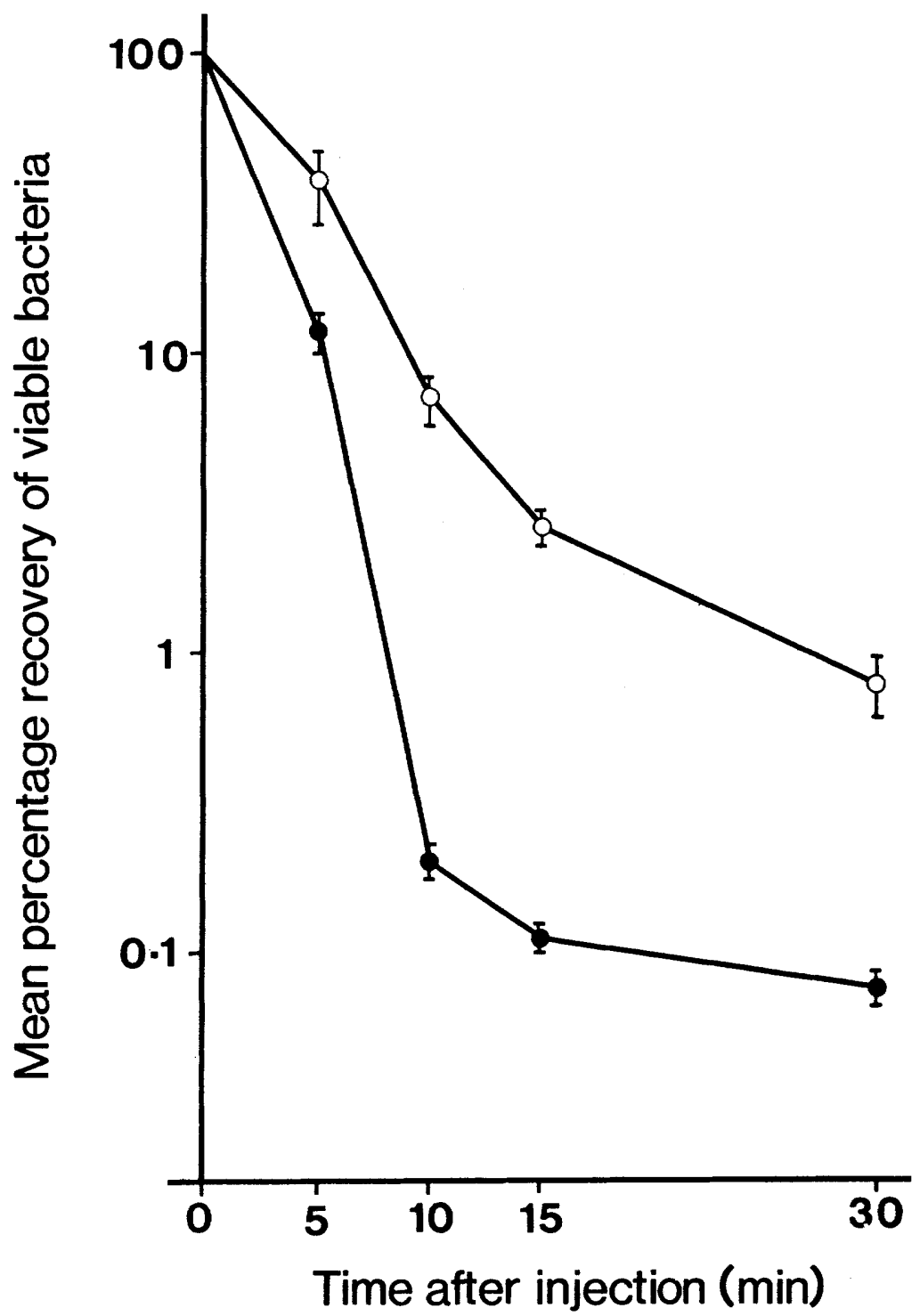

Fig. 4. Influence of initial injection of D-mannose into mice on clearance of bacteria from blood. Results are expressed as the mean recovery percentages (SD) in five mice. The clearance of Esch. coli H21 in mice given D-mannose before bacterial challenge was significantly slower than in control mice at all time intervals ( $p<0.01$ at $15 \mathrm{~min} ;<0.02$ at 5 and $30 \mathrm{~min}$ after bacterial challenge): $O$, mice given $100 \mathrm{mg}$ of $\mathrm{D}$-mannose $10 \mathrm{~min}$ before the bacterial challenge;, control.

Table III. Surface hydrophobicity of bacterial strains

\begin{tabular}{|c|c|c|c|}
\hline \multicolumn{2}{|c|}{ Systemic } & \multicolumn{2}{|c|}{ Portal } \\
\hline Strain & $\begin{array}{l}\text { Hydrophobicity* } \\
(\%)\end{array}$ & Strain & $\begin{array}{c}\text { Hydrophobicity* } \\
(\%)\end{array}$ \\
\hline$P$. aeruginosa D4 & $26 \cdot 33$ & Esch. coli $\mathrm{L} 33$ & 3.76 \\
\hline$P$. aeruginosa D271 & $16 \cdot 00$ & Esch. coli $\mathrm{L} 424$ & 0.49 \\
\hline$P$. aeruginosa $\mathrm{H} 3$ & $83 \cdot 71$ & Esch. coli L529 & 4.49 \\
\hline P. aeruginosa $\mathrm{H} 8$ & $79 \cdot 82$ & Esch. coli $\mathbf{H} 21$ & 0.92 \\
\hline P. aeruginosa $\mathrm{H} 9$ & 1.55 & Esch. coli $\mathrm{H} 25$ & 0.03 \\
\hline P. aeruginosa $\mathrm{H} 12$ & 1.90 & E. cloacae $\mathrm{L} 31$ & -5.93 \\
\hline P. aeruginosa $\mathrm{H} 13$ & 83.25 & E. cloacae L317 & $3 \cdot 55$ \\
\hline$P$. aeruginosa $\mathrm{H} 15$ & $4 \cdot 42$ & E. cloacae L522 & -0.44 \\
\hline M. morganii L48 & $66 \cdot 73$ & E. cloacae L527 & 3.08 \\
\hline M. morganii L222 & $-3 \cdot 45$ & K. pneumoniae $\mathrm{H} 29$ & $7 \cdot 70$ \\
\hline M. morganii $\mathrm{L} 322$ & -1.80 & Ent. faecalis L425 & 86.72 \\
\hline M. morganii L421 & $75 \cdot 22$ & Ent. faecium L211 & 79.95 \\
\hline M. morganii $\mathrm{H} 32$ & $9 \cdot 13$ & Ent. faecium L410 & $33 \cdot 22$ \\
\hline M. morganii $\mathrm{H} 35$ & $22 \cdot 60$ & & \\
\hline
\end{tabular}

* Results are expressed as means of three assays. 


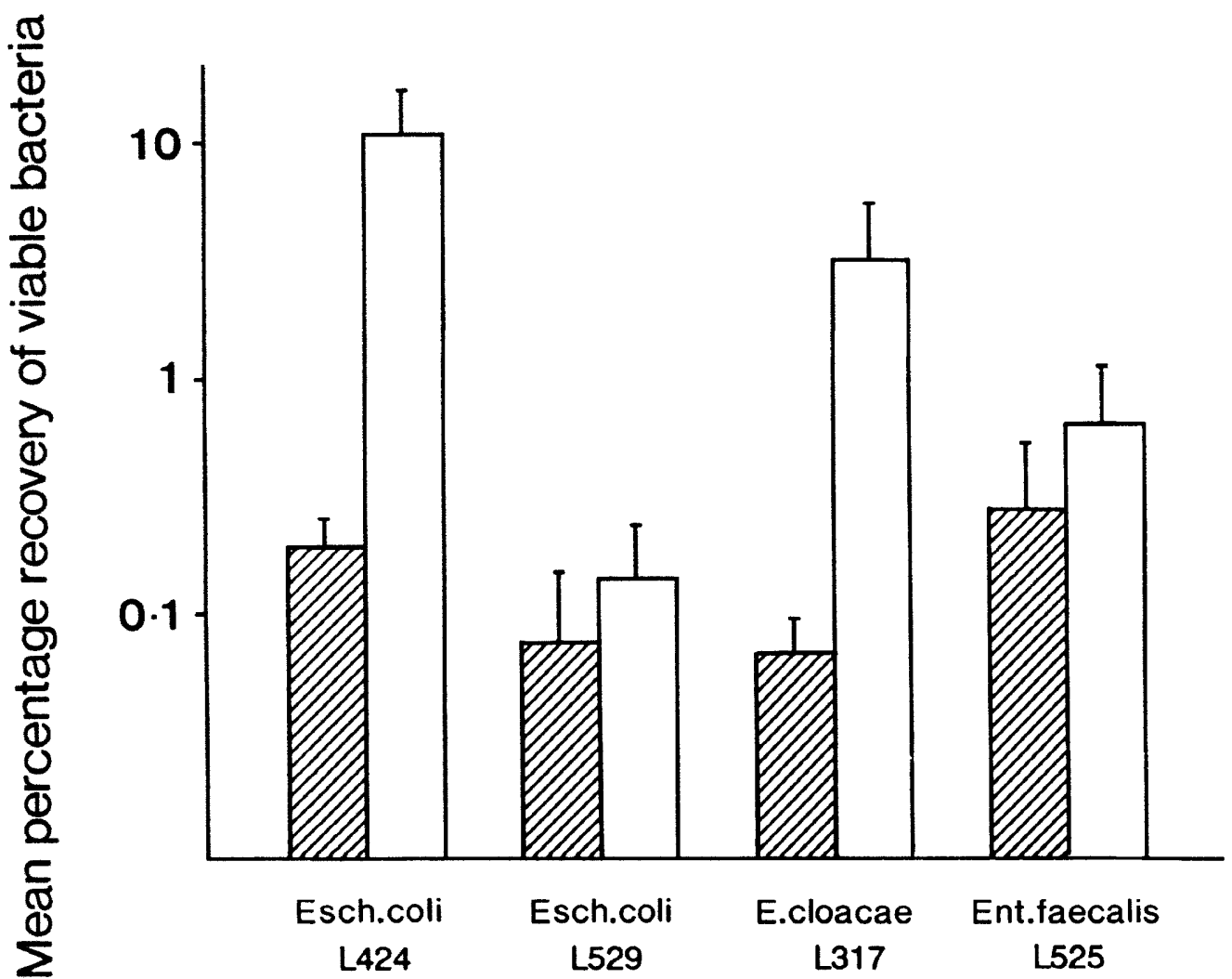

Fig. 5. Clearance of portal strains from blood in CBA/J $(\square)$ and $C B A / N(\square)$ mice. Results are expressed as the mean recovery percentages (SD) in five mice $30 \mathrm{~min}$ after bacterial challenge. The clearance of Esch. coli L424 and E. cloacae L317 in CBA/N mice was significantly slower than in CBA/J mice ( $\mathrm{p}<0.01$ and 0.05 , respectively). No differences were observed with Esch. coli L529 and Ent. faecalis L425.

\section{Results}

\section{Blood clearance of bacteria in mice}

Blood clearance rates of $P$. aeruginosa, and $M$. morganii strains are shown in figs. la and b. Blood clearance rates of portal strains are shown in fig. 2 . The portal strains were cleared significantly more rapidly than the systemic strains at every time interval; $57.98 \%$ (SD 36.62) and $12.67 \%$ (SD 8.60) of viable bacteria remained in the blood of mice 5 min after injection of systemic and portal bacteraemic strains respectively $(\mathrm{p}<0.01)$. At $30 \mathrm{~min}$ after injection, $18.25 \%$ (SD 26.38) of bacteria of systemic strains were recovered whereas only $0.10 \%$ (SD 0.07 ) of portal strains were recovered $(p<0.05)$.

Agglutination of bacterial strains with mannosylated beads, Con A, and UEA I

Table II shows that Esch. coli strains L424, H21 and $\mathrm{H} 25$, E. cloacae strains L31, L317, L522 and L527, and Ent. faecium strains L211 and L410 were mannosesensitive, indicating that these strains carry mannosetype lectin on their surfaces. All other bacterial strains, including $P$. aeruginosa D4 and $M$. morganii L48 failed to agglutinate mannosylated beads and were considered not to be mannose sensitive. On the other hand, Esch. coli strains L33, H21 and H25, E. cloacae strains L31, L317 and L527, K. pneumoniae H29, Ent. faecalis L425, and Ent. faecium strains L211 and L410 agglutinated with Con $\mathrm{A}$, and agglutination was inhibited by mannose. E. cloacae strains L317 and L527 also showed agglutination with UEA-I that could be inhibited by glucose.

\section{Inhibition of blood clearance by sugars}

As shown in fig. 3, clearance of mannose-sensitive strain Esch. coli L424 was not inhibited by preincubation of D-mannose with bacteria to block their surface mannose-type lectin. No difference was found between blood clearance rates of D-mannose treated bacteria and controls with the other mannose-sensitive strains.

On the other hand, fig. 4 demonstrates that the blood clearance of Esch. coli $\mathrm{H} 21$ was inhibited by injection of D-mannose into mice before bacterial challenge. At $30 \mathrm{~min}$ after challenge, $0.77 \%$ (SD 0.17) of viable bacteria could be recovered from $D$-mannosetreated mice, compared with $0.08 \%$ (SD 0.01 ) from control mice $(p<0.01)$. However, the clearance of other strains that agglutinated with Con A or UEA-1 was not inhibited by pre-treatment of mice with Dmannose, D-galactose, or D-fucose (data not shown).

\section{Bacterial cell-surface hydrophobicity}

As shown in table III, the hydrophobicity of systemic strains ranged from $-3.45 \%$ to $83.71 \%$. The 


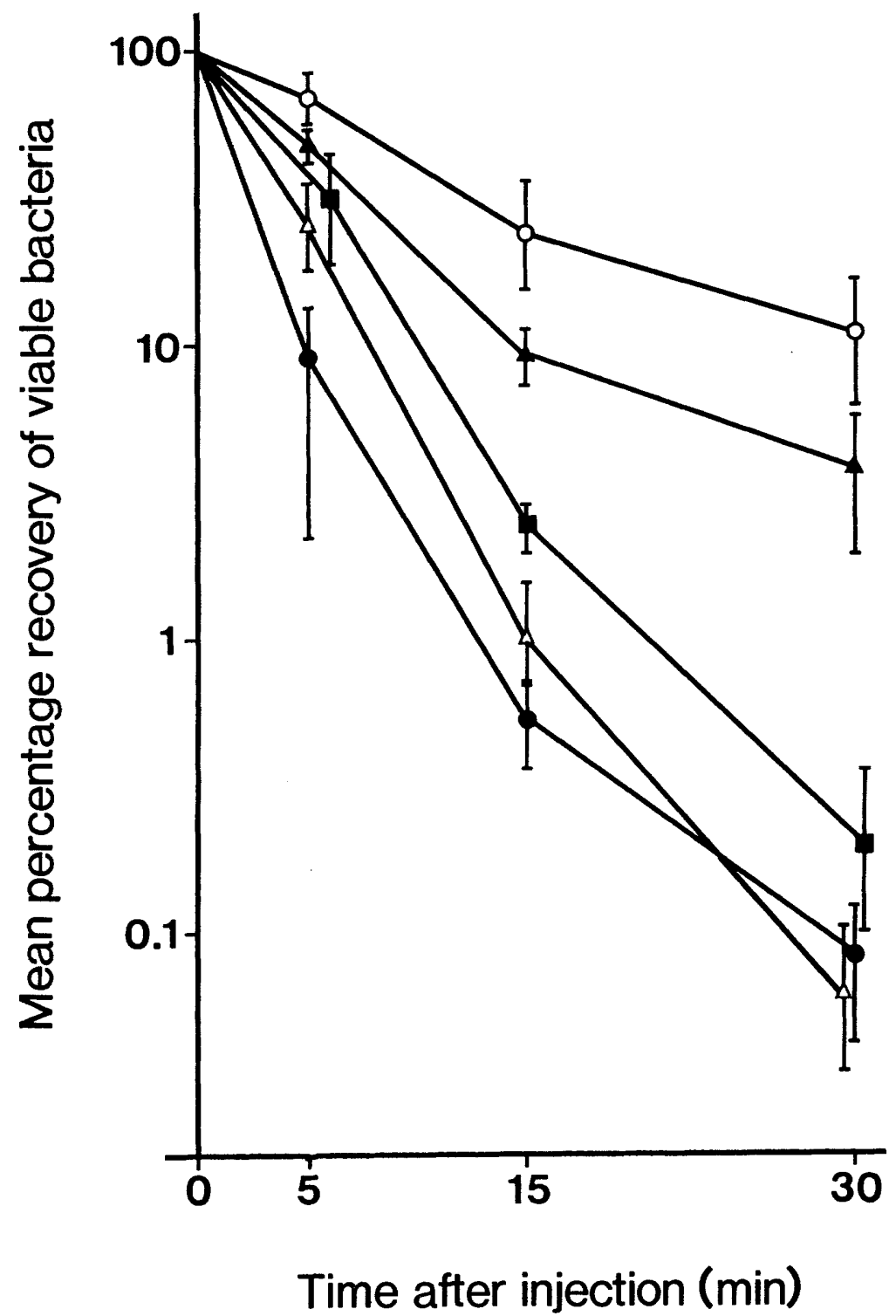

Fig. 6. Influence of transfer of serum from CBA/J mice into CBA/N mice on clearance of Esch. coli $\mathrm{L} 424$ from blood. Results are expressed as the mean recovery percentages (SD) in five mice. The clearance of Esch. coli L424 in CBA/N mice given heat-inactivated serum or heatinactivated serum absorbed with Esch. coli L529 was significantly faster than in CBA/N mice that were untreated or had been given heatinactivated serum absorbed with Esch. coli $\mathrm{L} 424(\mathrm{p}<0.01): O$, untreated CBA/N mice;, $\mathrm{CBA} / \mathrm{N}$ mice given heat-inactivated serum; $\triangle$, CBA/N mice given heat-inactivated serum absorbed with Esch. coli L529; $\triangle$, CBA/N mice given heat-inactivated serum absorbed with Esch. coli $\mathrm{L} 424 ; 0, \mathrm{CBA} / \mathrm{J}$ mice.

gram-negative bacteria causing portal bacteraemia showed little or no affinity with hexadecane. In contrast, Ent. faecalis L424 and Ent. faecium strains L211 and L410 showed significantly higher hydrophobicity compared with systemic strains and gramnegative portal strains $(\mathrm{p}<0.01)$.

\section{Blood clearance of portal bacteraemic strains in $C B A / J$ and $C B A / N$ mice}

As shown in fig. 5, significantly greater numbers of Esch. coli L424 and E. cloacae L317 were recovered from the blood of CBA/N mice than from CBA/J mice ( $p<0.01$ and 0.05 , respectively). No differences were observed between $\mathrm{CBA} / \mathrm{J}$ and CBA/N mice in blood clearance of Esch. coli L529 or Ent. faecalis L425.
Fig. 6 shows that transfer of heat-inactivated serum or heat-inactivated serum absorbed with Esch. coli L529 obtained from CBA/J mice into CBA/N mice significantly enhanced the blood clearance of Esch.coli L424 ( $<<0.01)$ at all time intervals. However, heatinactivated serum absorbed with Esch. coli L424 did not enhance the blood clearance of this strain in $\mathrm{CBA} / \mathrm{N}$ mice.

\section{Discussion}

Results suggest that the blood clearance of bacteria isolated from the portal circulation of mice is generally more rapid than that of systemic strains. Opsonic phagocytosis and non-opsonic phagocytosis seem to act as complementary processes in protection against invading micro-organisms. 
Some studies with Salmonella typhimurium,,$^{13}$ Esch. coli, ${ }^{14}$ and Serratia marcescens ${ }^{15}$ have shown that blood clearance or liver clearance of these microorganisms is mediated by lectinophagocytosis. In this study most bacterial strains that were cleared rapidly from blood carried single or multiple factors on their surfaces facilitating lectinophagocytosis. Indeed, blood clearance of Esch. coli $\mathrm{H} 21$ could be inhibited by prior injection of mannose into the mice, indicating that the clearance of this strain was mediated by mannose-type lectin on the surface of tissue macrophages, but blood clearance of other strains was not inhibited by giving initial mannose, galactose or fucose to block corresponding lectins on the surfaces of macrophages, nor by incubation of bacteria with mannose to block their surface mannose-type lectin. These findings suggest that either lectinophagocytosis was ineffective or that additional factors may be involved in the clearance of these strains from the bloodstream.

Bacterial cell-surface hydrophobicity has been also cited as an important factor in mediating phagocytosis, ${ }^{8}$ but in this study no correlation was found between bacterial cell-surface hydrophobicity and blood clearance, except for enterococci. P. aeruginosa and $M$. morganii strains that resisted blood clearance showed greater hydrophobicity than did isolates that were eliminated rapidly from blood.

We demonstrated previously that normal murine serum enhanced bacterial association with Kupffer cells only for Ent. faecalis L425 but not for gram-

\section{References}

1. Katz S, Jimenez MA. Lehmkuhler WE, Grosfeld JL. Liver bacterial clearance following hepatic artery ligation and portacaval shunt. J Surg Res 1991; 51: 267-270.

2. Katz S, Plaisier BR, Folkening WJ, Grosfeld JL. Intralipid adversely affects reticuloendothelial bacterial clearance. $J$ Pediatr Surg 1991: 26: 921-924.

3. Praaning-van Dalen DP, Brouwer A, Knook DL. Clearance capacity of rat liver Kupffer, endothelial, and parenchymal cells. Gastroenterology $1981 ; 81$ : 1036-1044.

4. Rogers DE. Host mechanisms which act to remove bacteria from the blood stream. Bacteriol Rev $1960 ; 24: 50-66$

5. Biozzi $G$, Stiffel $C$. The physiopathology of the reticuloendothelial cells of the liver and spleen. In: Popper $\mathrm{H}$, Schaffener $F$ (eds) Progress in liver diseases, vol II. London, William Heinemann Medical Books. 1965: 166191.

6. Saba TM. Physiology and physiopathology of the reticuloendothelial system. Arch Intern Med 1970; 126: 10311052 .

7. Ofek I, Sharon N. Lectinophagocytosis: a molecular mechanism of recognition between cell surface sugars and lectins in the phagocytosis of bacteria. Infect Immun 1988; 56: 539-547.

8. Absolom DR. The role of bacterial hydrophobicity in infection: bacterial adhesion and phagocytic ingestion. Can J Microbiol 1988; 34 : 287-298.

9. Speert DP, Eftekhar F, Puterman ML. Nonopsonic phagocytosis of strains of Pseudomonas aeruginosa from cystic fibrosis patients. Infect Immun 1984; 43: 1006-1011.

10. Boner G, Mhashilkar AM, Rodriguez-Ortega M, Sharon N. Lectin-mediated, nonopsonic phagocytosis of type Escherichia coli by human peritoneal macrophages of uremic patients treated by peritoneal dialysis. $J$ Leukoc Biol 1989: 46: 239-245.

11. Sharon N, Ofek I. Mannose-specific bacterial surface lectins. negative bacteria ${ }^{16}$ and that bacterial association of these gram-negative bacteria did not decrease at $4^{\circ} \mathrm{C}$ in vitro. Such findings suggest that association of these strains with Kupffer cells may be mediated by nonopsonic phagocytosis. However, in this in-vivo study there were significant differences between blood clearance of some portal strains in CBA/N mice with $\mathrm{X}$ linked immunodeficiency in $\mathrm{B}$ cells that lack normally differentiated B-1 cells, ${ }^{20,21}$ and clearance in CBA/J mice. Moreover, blood clearance of Esch. coli L424 in CBA/N mice was enhanced by transfer of serum obtained from CBA/J mice. The absorption of the serum with Esch. coli L424 before transfer strikingly suppressed the enhancement of blood clearance. These observations indicate that specific or cross-reactive antibodies against this organism may have existed in the mice used and contributed to elimination of this strain from the blood.

We have shown that the significant differences in blood clearance between the systemic and portal strains are common in the various strains used in this study. These findings indicate that elimination of bacteria may be critical in determining whether latent portal bacteraemia progresses to systemic bacteraemia. Our data suggest that opsonophagocytosis, lectinophagocytosis or hydrophobic interaction are involved in clearance from the circulation of mice of some bacterial strains, but other factors are probably involved also. Further studies are required to clarify the mechanism of the blood clearance of these strains.

In: Mirelman D (ed) Microbial lectins and agglutinins: properties and biological activity. New York, John Wiley and Sons Inc. 1986; 55-81.

12. Ashwell G, Harford J. Carbohydrate-specific receptors of the liver. Annu Rev Biochem 1982; 51: 531-554.

13. Leunk RD, Moon RJ. Association of type 1 pili with the ability of livers to clear Salmonella typhimurium. Infect Immun 1982; 36: 1168-1174.

14. Perry A, Ofek I. Inhibition of blood clearance and hepatic tissue binding of Escherichia coli by liver lectin-specific sugars and glycoproteins. Infect Immun 1984; 43: 257-262.

15. Rumelt S, Metzger Z, Kariv N, Rosenberg M. Clearance of Serratia marcescens from blood in mice: role of hydrophobic versus mannose-sensitive interactions. Infect Immun 1988; 56: 1167-1170.

16. Hirakata $\mathrm{Y}$, Tomono $\mathrm{K}$, Tateda $\mathrm{K}$ et al. Role of bacterial association with Kupffer cells in occurrence of endogenous systemic bacteremia. Infect Immun 1991; 59: 289-294.

17. Rosenberg M, Gutnick D, Rosenberg E. Adherence of bacteria to hydrocarbons: a simple method for measuring cellsurface hydrophobicity. FEMS Microbiol Lett 1980; 9 : 29-33.

18. O'Brien AD, Scher I, Campbell GH, MacDermott RP, Formal SB. Susceptibility of $\mathrm{CBA} / \mathrm{N}$ mice to infection with Salmonella typhimurium: influence of the $\mathrm{X}$-linked gene controlling B lymphocyte function. $J$ Immunol $1979 ; 123$ : 720-724.

19. Scher I. CBA/N immune defective mice: evidence for the failure of a B cell subpopulation to be expressed. Immunol Rev 1982; 64: 117-136.

20. Kantor A. A new nomenclature for B cells. Immunol Today $1991 ; 12: 388$.

21. Pecquet SS, Ehrat C, Ernst PB. Enhancement of mucosal antibody responses to Salmonella typhimurium and the microbial hapten phosphorylation in mice with X-linked immunodeficiency by B-cell precursors from the peritoneal cavity. Infect Immun 1992; 60: 503-509. 